\title{
Assessing expectations of Physician Assistant program applicants using the Problem-Based Learning Readiness Questionnaire: Effect of a 1-hour PBL experience
}

\author{
Susan Hawkins \\ Chatham University, hawkins@chatham.edu \\ John Laird \\ Chatham University, laird@chatham.edu \\ Anthony Goreczny \\ Chatham University, goreczny@chatham.edu
}

Follow this and additional works at: https://nsuworks.nova.edu/ijahsp

Part of the Medical Education Commons, and the Scholarship of Teaching and Learning Commons

\section{Recommended Citation}

Hawkins S, Laird J, Goreczny A. Assessing expectations of Physician Assistant program applicants using the Problem-Based Learning Readiness Questionnaire: Effect of a 1-hour PBL experience. The Internet Journal of Allied Health Sciences and Practice. 2018 Jan 01;16(2), Article 3.

This Manuscript is brought to you for free and open access by the College of Health Care Sciences at NSUWorks. It has been accepted for inclusion in Internet Journal of Allied Health Sciences and Practice by an authorized editor of NSUWorks. For more information, please contact nsuworks@nova.edu. 


\title{
Assessing expectations of Physician Assistant program applicants using the Problem-Based Learning Readiness Questionnaire: Effect of a 1-hour PBL experience
}

\begin{abstract}
Purpose: Physician Assistant (PA) programs using problem-based learning (PBL) and other self-directed learning pedagogies must inform applicants of the nature of this type of curriculum. The purpose of this study is to determine if the author-composed PBL Readiness Questionnaire can detect changes in applicant expectations of self, others, and facilitators following a one-hour PBL experience.

Method: Applicants to a Physician Assistant program took part in a one-hour PBL experience as part of their admissions interview process and 729 completed the PBL Readiness Questionnaire before and after the experience.

Results: Analysis of variance showed a significant increase in pre versus post total score $(p=.000)$. Multivariate analysis of variance of pre versus post subscale scores of expectations of self, others, and facilitators was also significant $(p=0.000)$. Conclusions: The PBL Readiness Questionnaire significantly changed applicant expectations of self, others, and facilitators in the direction consistent with PBL pedagogy. PA programs using problem-based learning and/or other self-directed learning pedagogies could use this scale to detect changes in applicant expectations following admissions processes. Future studies could determine effectiveness of scores in predicting student outcomes.
\end{abstract}

Keywords: problem-based learning, admissions, small group learning, pedagogy, case based learning

\section{Author Bio(s)}

Susan Hawkins, MSEd., PA-C, is an associate professor and Problem-based Learning (PBL) Coordinator in the Physician Assistant Studies program at Chatham University in Pittsburgh, PA. She also does PBL trainings for faculty nationwide and serves as an ARC-PA accreditation site visitor.

John Laird, ND is an associate professor in the Physician Assistant Studies program at Chatham University in Pittsburgh, PA, where he teaches the basic medical sciences. He also has a clinical practice in naturopathic medicine at the Center for Integrative Medicine of the University of Pittsburgh Medical Center.

Anthony J. Goreczny, Ph.D. is a professor in the Counseling Psychology program at Chatham University in Pittsburgh, PA,. He maintains a private practice with interests in the areas of Developmental Disabilities, Health Psychology, Assessment, Clinical and Educational Psychology, and Ethical, Legal and Psychological Implications of Genetics Technologies.

\section{Acknowledgements}

The authors wish to acknowledge Mark Hertweck, MA, PA-C for his work in the development and administration of the PBL Readiness Questionnaire as well as early development of the study. 


\title{
IJAHSP \\ The Internet Joưnal of Allied Health Sciences and Practice
}

Dedicated to allied health professional practice and education

Vol. 16 No. 2 ISSN 1540-580X

\section{Assessing Expectations of Physician Assistant Program Applicants Using the Problem-Based Learning Readiness Questionnaire: Effect of a One-Hour PBL Experience}

\author{
Susan Hawkins, MSEd., PA-C \\ John Laird, ND \\ Anthony Goreczny, Ph.D. \\ Chatham University \\ United States
}

\begin{abstract}
Purpose: Physician assistant $(\mathrm{PA})$ programs that use problem-based learning (PBL) and other self-directed learning pedagogies must inform applicants of the nature of this type of curriculum. The purpose of this study was to determine if the author-composed PBL Readiness Questionnaire could detect changes in applicant expectations of self, others, and facilitators, following a one-hour PBL experience. Method: Applicants to a physician assistant program took part in a one-hour PBL experience as part of their admissions interview process, and 729 completed the PBL Readiness Questionnaire before and after the experience. Results: Analysis of variance showed a significant increase in pre versus post total score $(p=.000)$. Multivariate analysis of variance of pre versus post subscale scores of expectations of self, others, and facilitators was also significant $(p=0.000)$. Analysis of variance showed a significant increase in pretest versus posttest total score $(p=.000)$. Multivariate analysis of variance of pretest versus posttest subscale scores of expectations of self, others, and facilitators was also significant $(p=.000)$. Conclusions: The applicant expectations of self, others, and facilitators were significantly changed by using the PBL Readiness Questionnaire, which was consistent with PBL pedagogy. PA programs using problem-based learning and/or other self-directed learning pedagogies could use this scale to detect changes in applicant expectations following admissions processes. Future studies could determine effectiveness of scores in predicting student outcomes.
\end{abstract}

Problem-based learning (PBL) is regarded as an effective pedagogy for graduate medical education because it fosters learning in a format that is representative of a student's future medical practice. ${ }^{1} \mathrm{PBL}$ has been variably incorporated into graduate physician assistant (PA) education for similar reasons. The Chatham University PA program developed a PBL-only curriculum in 1997. By 2003, there were three additional PA programs with a PBL predominant curricula: Southern Illinois University, University of New Mexico, and one track in Western Michigan University. ${ }^{2}$ Results of a survey of PA programs in 2005 indicated that $76 \%$ of programs had incorporated aspects of PBL in their curricula, but a minority of programs used PBL as the sole pedagogical method. ${ }^{3}$ The aspects of PBL that make it an effective model for learning medicine also make it challenging for students. With PBL, students are required to develop new skills in collaborative, small group learning and active self-directed learning. ${ }^{4}$ For PA students who are primarily focused on learning the content of medicine, these skills are unanticipated and unrecognized as integral to an effective PBL-centered program. Students are surprised to learn the degree to which they must decide which topics to learn, how much to learn, and the depth of learning without overt faculty direction. They are initially unfamiliar with their role as team members and of their interdependence and shared responsibility for learning. They learn that for a PBL group to be effective, each member is required to develop and utilize skills in professional behavior, communication, and social support. ${ }^{4}$ For students accustomed to a predominantly passive lecture-based undergraduate education, the transition to PBL is stressful. In a six-year longitudinal study of PA students in a dual track PA program, Wardley et al found that PBL students had significantly greater stress from school work during their first didactic year compared with the lecture-based students. ${ }^{5}$ 
It has been recommended that students develop an understanding of the PBL process and their role in it to reduce stress and improve academic and professional outcomes. ${ }^{4}$ Graduate programs have developed several strategies to facilitate a student's transition to a PBL-centered curriculum. For instance, some programs have incorporated education about PBL in their admissions materials, Web pages, and interview-day activities. ${ }^{6,7}$ Some medical programs have instituted orientation workshops or classes for the teaching of the fundamentals of adult learning of which PBL is an example. ${ }^{8} \mathrm{~A}$ first-year, PBL-based Introduction to Medicine course in a Japanese medical school showed a significant increased students' understanding of selfdirected learning and the usefulness of PBL. ${ }^{9}$

Because of the importance of self-directed learning in medical education, some medical schools have attempted to identify applicants and students who are good self-directed learners. One of the most commonly used instruments for this purpose is the Self-Directed Learning Readiness Scale (SDLRS). ${ }^{10}$ Using previously established norms, this scale has differentiated high versus low readiness for self-directed learning among fifth-semester medical students in south India, first-year undergraduate medical students in Nepal, and Doctor of Pharmacy (PharmD) students in the United States. ${ }^{11-13}$ However, with the SDLRS, levels of self-directed learning readiness among 249 applicants to a PA program that utilized PBL were not differentiated. Nearly all of the PA applicants were identified as having a high readiness for self-directed learning. ${ }^{14} \mathrm{~A}$ reason for the lack of differentiation is the SDLRS may not contain items that identify readiness for small-group PBL learning because in that study, Hawkins et al co-administered faculty-developed questionnaire containing 10 items that assessed readiness for a small group and found that PBL did demonstrate a significant change in readiness after students participated in a one-hour PBL experience during the interview-day activities. ${ }^{14,15}$ Hawkins et al subsequently developed a 71-item PBL Readiness Questionnaire that was focused on three aspects of PBL small group learning: expectations of self, others, and the facilitator. The questionnaire was administered to 60 PA students at the beginning and end of the didactic year, which demonstrated a significant change in expectations of self and the facilitator that were consistent with effective PBL behaviors. ${ }^{16}$ The purpose of our study was to extend initial research on the PBL Readiness Questionnaire to determine if it was sensitive enough to detect changes in PA applicant expectations of self, others, and facilitators in a large, multi-year sample.

\section{METHODS}

The subjects were 804 applicants of a university-based, 2-year, master's-level PA program who were invited to participate in an interview day during three admissions cycles from November 2013 through December 2015. The admissions process included (1) a one-hour presentation about the PA program curriculum; (2) a one-hour group interview with three applicants, 2 to 3 PA program faculty members, and community PAs; and (3) a voluntary one-hour PBL experience. The purpose of the PBL experience as part of the admissions process was to make certain that applicants were aware of the self-directed nature of the curriculum. Approval for this study was granted by the University's Institutional Review Board. All subjects received a copy of the PBL Readiness Questionnaire, which contained notification that completion of the form indicated consent to participate in the study. This questionnaire was developed by the authors and consisted of 71 items using a 10-point Likert scale, ranging from 1 , strongly disagree to 10 , strongly agree.

During the 3 years of admissions cycles, 811 applicants were interviewed (255 in 2013-2014, 274 in 2014-2015, and 282 in 20152016). Completed questionnaires were submitted by 804 applicants (254 in 2013-2014, 271 in 2014-2015, and 279 in 2015-2016), for a $99.1 \%$ return rate $(99.6 \%$ in $2013-2014,98.9 \%$ in $2014-2015$, and $98.9 \%$ in 2015-2016). Applicants were assigned to groups of approximately 18 participants with each group led by one clinical phase, second-year PA student who had been trained in PBL facilitation. Applicants completed the PBL Readiness Questionnaire before the PBL experience. The facilitator used a case based on the Southern Illinois University PBL case format. After brief introductions, applicants were given the simulated patient's presenting problem and developed a differential diagnosis list. Applicants asked questions of the simulated patient for which they received pre-programmed answers and were able to ask for physical examination results, which were given upon inquiry. Facilitators asked questions to probe the applicants' depth of knowledge because this activity is part of the self-directed learning model used in the curriculum. At the end of the experience, the facilitator told applicants the outcome of the simulated patient. The PBL Readiness Questionnaire was then re-administered after the PBL experience. Pretest and posttest questionnaires were contained in the same envelope with the same number attached in order to match pretest and posttest participant data. A research assistant, who was not one of the authors, created a listing that linked participants' names and numbers; however, the list was not made available to the authors to ensure anonymity of responses. No demographic or other identifying information was collected. Data were stored in a locked faculty office in a locked cabinet. Computer data were stored on a password-protected computer. Data were entered into Microsoft Excel 2015 and then migrated into SPSS 18 software, which was used for all data analyses, including multivariate analyses of variance (MANOVA) and univariate analyses of variance (ANOVA). Prior to computation of the MANOVA and ANOVAs, we computed pretest and posttest scores for all participants for the total readiness score and for each subscale (self, others, and facilitator).

(C) The Internet Journal of Allied Health Sciences and Practice, 2018 


\section{RESULTS}

Of the 804 participants who completed either the pretest or posttest questionnaire, 729 submitted complete questionnaires with no missing data points. Data were used only from those 729 participants. Mean and standard deviations of each item of the scale appear in Table 1.

\begin{tabular}{|c|c|c|c|}
\hline Item & Scale & $\begin{array}{c}\text { Pretest } \\
\text { Mean }(S D+)\end{array}$ & $\begin{array}{c}\text { Posttest } \\
\text { Mean }(S D+)\end{array}$ \\
\hline 1. I expect others to be respectful to all members of the group. & $\mathrm{O}^{* *}$ & $\begin{array}{c}9.86 \\
(0.55)\end{array}$ & $\begin{array}{c}9.88 \\
(0.42)\end{array}$ \\
\hline 2. I expect to learn more on my own than from other group members. & $\mathrm{S}^{* *}$ & $\begin{array}{c}4.87 \\
(2.12)\end{array}$ & $\begin{array}{c}4.50 \\
(2.40)\end{array}$ \\
\hline 3. I expect to remain an individual first and a group member second. & $S$ & $\begin{array}{c}4.92 \\
(2.32)\end{array}$ & $\begin{array}{c}4.57 \\
(2.28)\end{array}$ \\
\hline 4. I expect to accommodate to others in the group. & $\mathrm{S}$ & $\begin{array}{c}8.49 \\
(1.51) \\
\end{array}$ & $\begin{array}{c}8.93 \\
(1.37)\end{array}$ \\
\hline 5. I expect that I will contribute to the group's success. & $S$ & $\begin{array}{c}9.67 \\
(0.68) \\
\end{array}$ & $\begin{array}{c}9.73 \\
(0.66) \\
\end{array}$ \\
\hline 6. I expect to keep frustrations with others to myself when participating in a group.* & $\mathrm{S}$ & $\begin{array}{c}3.91 \\
(2.33) \\
\end{array}$ & $\begin{array}{c}5.30 \\
(2.54)\end{array}$ \\
\hline 7. I expect to keep the group unaware of my frustrations with myself. ${ }^{*}$ & $S$ & $\begin{array}{c}4.79 \\
(2.52)\end{array}$ & $\begin{array}{c}5.78 \\
(2.56)\end{array}$ \\
\hline 8. I expect myself to work hard in the group. & $\mathrm{S}$ & $\begin{array}{c}9.88 \\
(0.43)\end{array}$ & $\begin{array}{c}9.90 \\
(0.41)\end{array}$ \\
\hline 9. I expect myself to come to group having completed my assignments. & S & $\begin{array}{l}9.87 \\
(0.61)\end{array}$ & $\begin{array}{c}9.89 \\
(0.51)\end{array}$ \\
\hline 10. I expect that I will work harder than others in the group. & $\mathrm{S}$ & $\begin{array}{c}7.56 \\
(1.92) \\
\end{array}$ & $\begin{array}{c}6.73 \\
(2.30) \\
\end{array}$ \\
\hline 11. I expect myself to support the group's goals. & $S$ & $\begin{array}{c}9.68 \\
(0.72) \\
\end{array}$ & $\begin{array}{c}9.74 \\
(0.67) \\
\end{array}$ \\
\hline 12. I expect myself to focus on my own goals. & $\mathrm{S}$ & $\begin{array}{c}7.99 \\
(1.99) \\
\end{array}$ & $\begin{array}{c}7.64 \\
(2.26)\end{array}$ \\
\hline 13. I expect myself to be patient with group members who want to move more slowly. & $S$ & $\begin{array}{c}8.91 \\
(1.18) \\
\end{array}$ & $\begin{array}{c}9.00 \\
(1.19) \\
\end{array}$ \\
\hline 14. I expect the group setting to motivate me to learn. & S & $\begin{array}{c}9.45 \\
(1.09) \\
\end{array}$ & $\begin{array}{c}9.63 \\
(0.94)\end{array}$ \\
\hline 15. I expect myself to keep my level of motivation to learn high in the group. & $S$ & $\begin{array}{c}9.73 \\
(0.61)\end{array}$ & $\begin{array}{c}9.76 \\
(0.60)\end{array}$ \\
\hline 16. I expect myself to keep pace with other members of the group. & $\mathrm{s}$ & $\begin{array}{c}9.44 \\
(0.88) \\
\end{array}$ & $\begin{array}{c}9.21 \\
(1.19) \\
\end{array}$ \\
\hline 17. I expect to do my share of the work for the group. & S & $\begin{array}{c}9.89 \\
(0.45) \\
\end{array}$ & $\begin{array}{c}9.86 \\
(0.56) \\
\end{array}$ \\
\hline 18. I expect that it will be easy for me to contribute to group discussions. & $S$ & $\begin{array}{c}9.11 \\
(1.10) \\
\end{array}$ & $\begin{array}{c}9.18 \\
(1.14) \\
\end{array}$ \\
\hline 19. I expect to complete my assignments for the group on time. & $S$ & $\begin{array}{c}9.90 \\
(0.38)\end{array}$ & $\begin{array}{c}9.88 \\
(0.41)\end{array}$ \\
\hline $\begin{array}{l}\text { 20. I expect to spend as much individual time as necessary to adequately complete my } \\
\text { group assignments. }\end{array}$ & S & $\begin{array}{c}9.48 \\
(1.21)\end{array}$ & $\begin{array}{c}9.60 \\
(1.10)\end{array}$ \\
\hline 21. I expect others will rate me as a good team member. & 0 & $\begin{array}{c}9.58 \\
(0.74)\end{array}$ & $\begin{array}{c}9.54 \\
(0.78)\end{array}$ \\
\hline 22. I expect that I will dominate group discussions. ${ }^{*}$ & $S$ & $\begin{array}{l}5.53 \\
(2.03)\end{array}$ & $\begin{array}{l}6.01 \\
(2.14)\end{array}$ \\
\hline 23. I expect myself to be open to feedback from others in the group. & $S$ & $\begin{array}{l}9.57 \\
(0.76)\end{array}$ & $\begin{array}{c}9.59 \\
(0.77) \\
\end{array}$ \\
\hline
\end{tabular}




\begin{tabular}{|c|c|c|c|}
\hline 24. I expect group members to be respectful of all members in the group. & 0 & $\begin{array}{c}9.83 \\
(0.54)\end{array}$ & $\begin{array}{c}9.84 \\
(0.47)\end{array}$ \\
\hline 25. I expect all group members will freely contribute new information to the group. & 0 & $\begin{array}{c}9.27 \\
(1.12)\end{array}$ & $\begin{array}{c}9.47 \\
(0.99)\end{array}$ \\
\hline 26. I expect everyone to contribute to the group's success. & 0 & $\begin{array}{c}9.63 \\
(0.78) \\
\end{array}$ & $\begin{array}{c}9.77 \\
(0.60) \\
\end{array}$ \\
\hline 27. I expect others to freely share their frustrations about me in the group. & 0 & $\begin{array}{c}7.86 \\
(2.07)\end{array}$ & $\begin{array}{c}8.08 \\
(1.87)\end{array}$ \\
\hline 28. I expect others to freely share their frustrations with themselves in the group. & 0 & $\begin{array}{c}7.41 \\
(2.01) \\
\end{array}$ & $\begin{array}{c}7.70 \\
(1.99)\end{array}$ \\
\hline 29. I expect other members of the group to maintain pace with the group. & 0 & $\begin{array}{c}8.52 \\
(1.40)\end{array}$ & $\begin{array}{c}8.24 \\
(1.70)\end{array}$ \\
\hline 30. I expect other members of the group to maintain pace with me. ${ }^{*}$ & 0 & $\begin{array}{c}3.53 \\
(1.85)\end{array}$ & $\begin{array}{c}3.60 \\
(2.03)\end{array}$ \\
\hline 31. I expect that others will easily contribute in group discussions. & 0 & $\begin{array}{c}8.22 \\
(1.62) \\
\end{array}$ & $\begin{array}{c}8.68 \\
(1.54)\end{array}$ \\
\hline 32. I expect others to do their share of the work in the group. & 0 & $\begin{array}{c}9.41 \\
(0.91)\end{array}$ & $\begin{array}{c}9.64 \\
(0.74)\end{array}$ \\
\hline 33. I expect all group members to be hard workers. & 0 & $\begin{array}{c}9.29 \\
(1.10) \\
\end{array}$ & $\begin{array}{c}9.52 \\
(0.87)\end{array}$ \\
\hline 34. I expect everyone to come to group having completed their assignments. & 0 & $\begin{array}{c}9.54 \\
(0.85) \\
\end{array}$ & $\begin{array}{c}9.72 \\
(0.71)\end{array}$ \\
\hline 35. I expect others to work harder than I do in the group. ${ }^{*}$ & 0 & $\begin{array}{c}7.17 \\
(2.33)\end{array}$ & $\begin{array}{c}6.91 \\
(2.53)\end{array}$ \\
\hline 36. I expect others to support the group's goals. & 0 & $\begin{array}{c}9.40 \\
(1.09)\end{array}$ & $\begin{array}{c}9.60 \\
(0.84)\end{array}$ \\
\hline 37. I expect others to support my goals. & 0 & $\begin{array}{c}7.83 \\
(1.94)\end{array}$ & $\begin{array}{c}8.31 \\
(1.90)\end{array}$ \\
\hline 38. I expect others to be patient with me when I want to move more slowly. & 0 & $\begin{array}{c}7.47 \\
(1.70) \\
\end{array}$ & $\begin{array}{c}7.89 \\
(1.55) \\
\end{array}$ \\
\hline $\begin{array}{l}\text { 39. I expect other group members to be patient with each other when some want to move } \\
\text { more slowly. }\end{array}$ & 0 & $\begin{array}{c}8.47 \\
(1.35) \\
\end{array}$ & $\begin{array}{c}8.59 \\
(1.31) \\
\end{array}$ \\
\hline \begin{tabular}{|l|}
40. \\
I expect the group setting to motivate others to learn.
\end{tabular} & 0 & $\begin{array}{c}9.44 \\
(0.86)\end{array}$ & $\begin{array}{c}9.64 \\
(0.77)\end{array}$ \\
\hline 41. I expect others to keep their level of motivation to learn high in the group. & 0 & $\begin{array}{c}9.42 \\
(0.87) \\
\end{array}$ & $\begin{array}{c}9.63 \\
(0.69) \\
\end{array}$ \\
\hline 42. I expect others to complete their assignments for the group on time. & 0 & $\begin{array}{c}9.63 \\
(0.75)\end{array}$ & $\begin{array}{c}9.78 \\
(0.54)\end{array}$ \\
\hline $\begin{array}{l}\text { 43. I expect others to spend as much individual time as necessary to complete adequately } \\
\text { their group assignments. }\end{array}$ & 0 & $\begin{array}{c}9.20 \\
(1.26) \\
\end{array}$ & $\begin{array}{c}9.42 \\
(1.13) \\
\end{array}$ \\
\hline 44. I expect that all others will be good team members. & 0 & $\begin{array}{c}8.99 \\
(1.36)\end{array}$ & $\begin{array}{c}9.25 \\
(1.15)\end{array}$ \\
\hline 45. I expect others in the group to be resistant to feedback from me.* & 0 & $\begin{array}{l}7.44 \\
(2.02)\end{array}$ & $\begin{array}{l}7.57 \\
(2.10)\end{array}$ \\
\hline 46. I expect the facilitator to be respectful of all members of the group. & $\mathrm{F}^{\star *}$ & $\begin{array}{l}9.77 \\
(0.58)\end{array}$ & $\begin{array}{c}9.78 \\
(0.72) \\
\end{array}$ \\
\hline $\begin{array}{l}\text { 47. I expect facilitators to keep frustrations with others to themselves when facilitating the } \\
\text { group.* }\end{array}$ & $\mathrm{F}$ & $\begin{array}{c}4.92 \\
(2.63)\end{array}$ & $\begin{array}{c}5.24 \\
(2.82)\end{array}$ \\
\hline 48. I expect facilitators to keep the group unaware of their frustrations with themselves. & $\mathrm{F}$ & $\begin{array}{c}5.52 \\
(2.62)\end{array}$ & $\begin{array}{c}5.21 \\
(2.65)\end{array}$ \\
\hline 49. I expect facilitators to have a plan for each session. & $\mathrm{F}$ & $\begin{array}{c}9.00 \\
(1.27) \\
\end{array}$ & $\begin{array}{c}7.51 \\
(2.51)\end{array}$ \\
\hline 50. I expect the facilitator to challenge me at every session. & $\mathrm{F}$ & $\begin{array}{c}9.35 \\
(1.02)\end{array}$ & $\begin{array}{c}9.43 \\
(1.22)\end{array}$ \\
\hline
\end{tabular}




\begin{tabular}{|c|c|c|c|}
\hline 51. I expect the facilitator to support the group's goals. & $\mathrm{F}$ & $\begin{array}{c}9.47 \\
(0.91) \\
\end{array}$ & $\begin{array}{c}9.32 \\
(1.32)\end{array}$ \\
\hline 52. I expect the facilitator to be patient when I am slow to understand a concept. & $\mathrm{F}$ & $\begin{array}{c}8.66 \\
(1.41)\end{array}$ & $\begin{array}{c}8.50 \\
(1.56)\end{array}$ \\
\hline 53. I expect the facilitator to push other group members when they are moving too slowly. & $\mathrm{F}$ & $\begin{array}{c}7.11 \\
(2.01)\end{array}$ & $\begin{array}{c}6.83 \\
(2.25)\end{array}$ \\
\hline 54. I expect the facilitator to set the pace of learning in the group. & $\mathrm{F}$ & $\begin{array}{c}7.68 \\
(1.96)\end{array}$ & $\begin{array}{c}6.27 \\
(2.66)\end{array}$ \\
\hline 55. I expect the facilitator to teach more than to guide. ${ }^{*}$ & $\mathrm{~F}$ & $\begin{array}{c}5.98 \\
(2.23)\end{array}$ & $\begin{array}{c}7.68 \\
(2.19)\end{array}$ \\
\hline 56. I expect different facilitators to provide a similar group experience. & $\mathrm{F}$ & $\begin{array}{c}6.24 \\
(2.38) \\
\end{array}$ & $\begin{array}{c}5.88 \\
(2.89)\end{array}$ \\
\hline 57. I expect the facilitator to assist me in identifying areas for further study. & $\mathrm{F}$ & $\begin{array}{c}8.28 \\
(1.63)\end{array}$ & $\begin{array}{c}7.71 \\
(2.40)\end{array}$ \\
\hline 58. I expect the facilitator to provide feedback about my strengths and weaknesses. & $\mathrm{F}$ & $\begin{array}{c}9.13 \\
(1.22)\end{array}$ & $\begin{array}{c}8.69 \\
(1.89)\end{array}$ \\
\hline 59. I expect the facilitator to focus on the knowledge base rather than the group process. & $\mathrm{F}$ & $\begin{array}{c}5.73 \\
(1.88)\end{array}$ & $\begin{array}{c}4.95 \\
(2.23)\end{array}$ \\
\hline $\begin{array}{l}\text { 60. I expect the facilitator to continue to ask questions about a topic when the group has } \\
\text { already identified that topic as requiring further study. }\end{array}$ & $\mathrm{F}$ & $\begin{array}{c}3.66 \\
(1.97)\end{array}$ & $\begin{array}{c}4.27 \\
(2.84)\end{array}$ \\
\hline 61. I expect the facilitator to limit the number of questions that they ask. ${ }^{*}$ & $\mathrm{~F}$ & $\begin{array}{c}7.19 \\
(2.08)\end{array}$ & $\begin{array}{c}7.58 \\
(2.48)\end{array}$ \\
\hline 62. I expect facilitator to foster self-directed learning during group sessions. & $\mathrm{F}$ & $\begin{array}{c}8.36 \\
(1.80)\end{array}$ & $\begin{array}{c}9.00 \\
(1.67)\end{array}$ \\
\hline 63. I expect the facilitator to lead the group sessions. ${ }^{*}$ & $\mathrm{~F}$ & $\begin{array}{c}5.16 \\
(2.26) \\
\end{array}$ & $\begin{array}{c}6.79 \\
(2.66) \\
\end{array}$ \\
\hline 64. I expect the facilitator to encourage us to rely on each other rather than on him or her. & $\mathrm{F}$ & $\begin{array}{c}8.78 \\
(1.34) \\
\end{array}$ & $\begin{array}{c}9.42 \\
(1.11)\end{array}$ \\
\hline 65. I expect the facilitator to provide clinically relevant stories during group sessions. & $\mathrm{F}$ & $\begin{array}{c}8.80 \\
(1.42) \\
\end{array}$ & $\begin{array}{r}7.98 \\
(2.42) \\
\end{array}$ \\
\hline 66. I expect the facilitator to tell me exactly what I need to know. ${ }^{*}$ & $\mathrm{~F}$ & $\begin{array}{c}6.76 \\
(2.40) \\
\end{array}$ & $\begin{array}{c}8.18 \\
(2.16) \\
\end{array}$ \\
\hline 67. I expect the facilitator to help me identify the limits of my knowledge. & $\mathrm{F}$ & $\begin{array}{c}7.53 \\
(2.29) \\
\end{array}$ & $\begin{array}{c}7.79 \\
(2.45) \\
\end{array}$ \\
\hline 68. I expect the facilitator to encourage me to rely on their expertise. ${ }^{*}$ & $\mathrm{~F}$ & $\begin{array}{c}5.76 \\
(2.50)\end{array}$ & $\begin{array}{c}6.69 \\
(2.75)\end{array}$ \\
\hline 69. I expect the facilitator to be open to feedback. & $\mathrm{F}$ & $\begin{array}{c}8.86 \\
(1.33) \\
\end{array}$ & $\begin{array}{r}8.80 \\
(1.62) \\
\end{array}$ \\
\hline 70. I expect to contribute as much as others to the group. & S & $\begin{array}{c}9.66 \\
(0.73)\end{array}$ & $\begin{array}{c}9.72 \\
(0.70)\end{array}$ \\
\hline 71. I expect the facilitator to tell me when I am wrong. ${ }^{*}$ & $\mathrm{~F}$ & $\begin{array}{c}2.95 \\
(2.13) \\
\end{array}$ & $\begin{array}{c}5.14 \\
(3.28)\end{array}$ \\
\hline
\end{tabular}

${ }^{*}$ Denotes items which were reverse scored such that high scores on all 71 items are consistent with PBL principles

${ }^{* *} \mathrm{O}$ denotes items regarding others. $\mathrm{S}$ denotes items regarding self. $\mathrm{F}$ denotes items regarding facilitator.

A one-way repeated measures multivariate analysis of variance with time of administration (pretest versus posttest) as the independent variable and each of the subscale scores (ie expectations of self, others, and facilitator) yielded a significant effect, multivariate $F(3,726)=56.05, p=.000$. Univariate analyses on each of the subscales indicated significant pretest-posttest differences for each of the subscales with all subscales increasing from pretest group activity to posttest group activity (Table 2). 
Table 2. Univariate Analyses of Subscale and Total Scores

\begin{tabular}{|c|c|c|c|c|}
\hline Scale & $\begin{array}{l}\text { Pretest Mean }(S D+) \\
{[\text { Per item average] }}\end{array}$ & $\begin{array}{l}\text { Posttest Mean }(S D+) \\
\text { [Per item average] }\end{array}$ & $F$ & $p$ \\
\hline $\begin{array}{c}\text { Self } \\
(n=22 \text { items })\end{array}$ & $\begin{array}{c}182.28(8.96) \\
{[8.29]}\end{array}$ & $\begin{array}{c}184.16(9.13) \\
{[8.38]}\end{array}$ & 44.69 & .000 \\
\hline $\begin{array}{c}\text { Others } \\
(n=24 \text { items })\end{array}$ & $\begin{array}{c}206.43(14.43) \\
{[8.60]}\end{array}$ & $\begin{array}{c}210.25(12.68) \\
{[8.77]}\end{array}$ & 106.11 & .000 \\
\hline $\begin{array}{c}\text { Facilitator } \\
(n=25 \text { items })\end{array}$ & $\begin{array}{c}180.62(11.04) \\
{[7.22]}\end{array}$ & $\begin{array}{l}184.63(13.89) \\
{[7.39]}\end{array}$ & 72.81 & .000 \\
\hline $\begin{array}{c}\text { Total } \\
(n=71 \text { items })\end{array}$ & $564.33(27.30)$ & $579.04(27.40)$ & $t=-12.78$ & .000 \\
\hline
\end{tabular}

A repeated measures (i.e. paired samples) $t$ test on total score also indicated a significant increase from pretest to posttest activity rating. The number of participants whose scores increased, decreased, or stayed the same for each of the subscales appears in Table 3. The majority of applicant scores increased in the direction consistent with PBL for all three subscales.

Table 3. Number of Subjects Whose Scores Increased, Decreased, or Stayed the Same on Each Subscale from Pretest to Posttest Activity

\begin{tabular}{|c|c|c|c|c|c|}
\hline Variable & $\begin{array}{c}\text { Number (percentage) } \\
\text { that decreased }\end{array}$ & $\begin{array}{c}\text { Number (percentage) } \\
\text { that stayed the same }\end{array}$ & $\begin{array}{c}\text { Number (percentage) } \\
\text { that increased }\end{array}$ & $\begin{array}{c}\text { Mean change } \\
(\mathbf{S D +}+)\end{array}$ & $\begin{array}{c}\text { Low Score } \\
\text { High Score }\end{array}$ \\
\hline Self & 281 & 33 & 415 & 1.88 & -32 \\
& $(38.55 \%)$ & $(4.53 \%)$ & $(56.93 \%)$ & $(7.59)$ & 33 \\
\hline Others & 245 & 33 & 451 & 3.82 & -32 \\
& $(33.61 \%)$ & $(4.53 \%)$ & $(61.87 \%)$ & $(10.02)$ & 51 \\
\hline Facilitator & 240 & 24 & 465 & 4.01 & -44 \\
& $(32.92 \%)$ & $(3.29 \%)$ & $(63.77 \%)$ & $(12.69)$ & 40 \\
\hline
\end{tabular}

\section{DISCUSSION}

By using a one-hour PBL experience, applicant expectations were changed for themselves (subscale 1), other group members (subscale 2), and the facilitator (subscale 3) in the direction consistent with PBL attitudes and behaviors and for the total score. Thus, the questionnaire is sensitive enough to detect change after only a one-hour PBL experience. The purpose of including this experience as part of the admissions process is to increase the likelihood that applicants understand the nature of a selfdirected learning curriculum; therefore, this questionnaire was useful for determining the effectiveness of this experience. Although the statistically significant average per item change is relatively small, it is meaningful when viewed in the context of the one-hour experience compared with a curricular experience, typically a minimum of one academic semester.

Although all subscales were significantly changed in the direction towards increased understanding of the PBL experience, the largest average change occurred in subscale 2, expectations of others, and subscale 3 , expectations of facilitators. With regard to the expectations of others, one possible explanation for this finding is that as undergraduates, applicants may not have engaged in optimally performing group-learning experiences. After observing the performance of fellow applicants in the PBL sessions, their expectations may have increased substantially. An additional possible explanation is that the one-hour PBL experience successfully accomplished its purpose of demonstrating the group dynamics integral to PBL, thus raising expectations of other group members. For future research, there needs to be an investigation into this possibility as well as how other undergraduate experiences prepare students for the rigor of graduate education, specifically for self-directed learning. Another possible explanation for the change in expectations of others is that applicants may have learned the most about the role of others in the one-hour PBL experience.

Some applicants were likely already familiar with their role in a group, and they did not need to learn the role of the facilitator during this one-hour experience; therefore, the greatest opportunity for learning was focusing on the role of others in the group. This finding indicates that the one-hour experience appears to be effective in educating applicants about the role of a group member in a PBL setting. 
The changes in expectations of facilitators was both positive news and somewhat surprising. It was surprising given that a onehour experience seems insufficient to have applicants recognize desired behaviors in a facilitator. The role of a facilitator is very different from traditional classroom teaching. The facilitator does not provide information but asks questions continually and asks applicants whether or not they agree with fellow group members. Applicants are likely to be more familiar with their own role and that of other students in group situations than they are with the role of someone facilitating PBL. Additionally, because this activity was a one-hour introductory session, the facilitator did not have as much of a chance to demonstrate typical facilitator behaviors as during a typical academic semester. For example, the brevity of the one-hour experience did not permit exploration of goals, which is an important part of the ongoing experience. Similarly, although evaluation is an important part of the PBL experience, it is not part of the one-hour experience. In addition, because the one-hour sessions are facilitated by students rather than faculty, some of the qualities might not be as well demonstrated as they were during ongoing sessions. The positive changes in subscale scores were promising given that the change took place after only one hour and especially given the nature of the session (i.e. during an admission interview process). Although applicants were assured that their performance in the one-hour experience did not affect their admissions status, applicants might have been reluctant to admit to not understanding the material. In any group process, group members may be reluctant to admit to not knowing information before building experience and trust of the group and facilitator, and there might have been an increased tendency to answer in a socially desirable manner. However, this behavior was not observed in our study. The questionnaire appeared to be sensitive enough to detect even changes after just one hour and in challenging circumstances, such as admissions interview processes, even though those processes have no bearing on admissions decisions.

Of note, there are many differences between demonstrating PBL to applicants versus using PBL with matriculants in a semesterlong course. When conducting PBL sessions with applicants, the goal is to have them focus on the process rather than the content because the purpose is to familiarize them with how the process differs from traditional lecture. During PBL for matriculants, however, the focus is the acquisition of knowledge, and the process becomes so familiar to students as to not require a lot of focus. The process is an important matter because recent research has indicated that facilitators play a key role in overall satisfaction with the PBL process. ${ }^{17}$ Additionally, applicants in an initial PBL exposure may be more focused on their own role and that of their group mates than on the role of the facilitator.

Another concern about the one-hour experience was that curricular exposure to PBL might be necessary for students to learn the values and behaviors of PBL for themselves and facilitators. This concern could have implications for faculty understanding that students may take a longer time than previously expected to make the transition to a PBL curriculum. Although students are expected to learn content at the beginning of a PBL curriculum, students are also simultaneously learning the process, which may make the knowledge acquisition more difficult at the start. Because of the differences between an example pre-admission PBL experience and real-PBL sessions with matriculated students, it is important to ensure that results from the current study could also be applicable to students in PBL-based programs. Hawkins et al examined administration of the PBL Readiness Questionnaire to matriculated physician assistant students that required those students to complete the questionnaire at the beginning and end of the nine-month didactic portion of a PBL PA curriculum. ${ }^{16}$ They found that student expectations of facilitators also changed in the direction of desired facilitator values as did expectations of others. This finding is supportive of the applicability of the PBL Readiness Questionnaire to both applicants and matriculated students.

One limitation of the current study was that the facilitators during the introductory sessions were second-year PA students rather than faculty members. Although they all completed 9 months of PBL PA didactic education and received facilitator training, they were not faculty. Use of second-year students rather than faculty may have contributed to different kinds of applicant responses. Applicants might not have held second-year students in the same level of esteem that they would a faculty member, potentially affecting their ratings of expectations of facilitator. In future research, this potential impact should be evaluated. The importance of training PBL facilitators is crucial for optimum performance. ${ }^{18} \mathrm{Additionally,} \mathrm{all} \mathrm{data} \mathrm{came} \mathrm{from} \mathrm{one} \mathrm{program.} \mathrm{The} \mathrm{reasoning}$ was that although PBL is used by many PA programs throughout the country, only a handful use PBL as the only pedagogy for their clinical medicine courses. Therefore, it would be difficult to track evaluative measures across programs consistently. In addition, there are multiple models of PBL; therefore, tracking evaluations across multiple programs would add an additional confounding factor. Therefore, although the data were collected from across 3 different years, it is important for additional programs to determine applicability to their programs, which would also help establish whether or not results from our study are generalizable to other programs. Finally, even though it was made clear to the applicants that no aspect of the PBL introductory session was part of the admissions criteria, applicants might have been influenced to look for desired answers. However, this factor would not explain why there was a change as shown from the pretest to posttest PBL experience. A final limitation could be the length of the survey. Although length did not affect completion rate of this questionnaire for this study sample, it could potentially affect other administrations of the questionnaire. Future research could use a shortened version of this questionnaire.

(C) The Internet Journal of Allied Health Sciences and Practice, 2018 
In the previous matriculant study, Hawkins et al showed that only 2 of the 3 categories (self and facilitator) changed significantly although the third (others) approached significance. ${ }^{16}$ Future research should explore how 1 one-hour introduction to PBL with PA program applicants might differ from a year-long curricular experience with matriculants. The two experiences are very different, but both showed differences from the pretest to posttest experience. Although this scale is based on literature related to PBL, other self-directed learning methodologies, such as case-based, team-based learning, and flipped classroom, have similar concepts. An example includes the de-emphasis of knowledge coming from the faculty member and replacing it with more critical thinking and self-directed learning on the part of the student; therefore, this scale could potentially be used by programs utilizing other small-group, self-directed learning teaching methodologies. ${ }^{19}$ Future studies with programs using such methodologies could investigate its usefulness for other types of small group learning. This activity could provide a tool for use by PA programs in admissions or program assessment, especially given its sensitivity in detecting changes after an experience of just one hour as well as changes that occurred across a semester experience.

\section{REFERENCES:}

1. Barrows HS. Practice-based Learning: Problem-based Learning Applied to Medical Education. Springfield, IL: Southern Illinois University School of Medicine; 1994.

2. Van Rhee JA, Wardley S, Hutchinson CA, Applegate EB, Vangsnes EH, et al. Problem-based learning in physician assistant education: Establishing a basis for a comparative study. Perspect Physician Assist Educ. 2003;14(4):242-8.

3. Scott Q, Lloyd L, Kelly C. Problem-based learning in physician assistant training programs. J Physician Assist Educ. 2005;16(2):84-8.

4. Bate B, Hommes J, Duvivier R, Taylor DC. Problem-based learning (PBL): Getting the most out of your students - their roles and responsibilities: AMEE Guide No. 84. Med Teach. 2014;36(1):1-12. [PMID: 24295273]

5. Wardley CS, Applegate EB, Almaleki AD, Van Ree JA. A comparison of students' perceptions of stress in parallel problem-based and lecture-based curricula. J Physician Assist Educ. 2016;27(1):7-16. [PMID: 26894948]

6. Midla GS, Coryell JE. Problem-based learning preparation for physician assistant faculty. US Army Med Dep J. 2010 Oct-Dec:39-47. [PMID: 21181673]

7. Chamberlain SE, Searle J. Assessing suitability for a problem-based learning curriculum: Evaluating a new student selection instrument. Med Educ. 2005 Mar;39(3):250-7. [PMID: 15733160]

8. Azer SA. Training students to learn in a problem-based learning programme. Med Ed. 2011;45:510. [PMID: 21486331]

9. Fujikura T, Nemoto T, Takayanagi K, Kahimura M, Hayasaka $Y$, Shimizu K. A freshman orientation program to provide an overview of the medical learning roadmap. J Nippon Med Sch. 2014;81(6):378-83. [PMID: 25744481]

10. Fisher M, King J, Tague $G$. Development of a self-directed learning readiness scale for nursing education. Nurse Educ Today. 2001;21(7):516-25. [PMID: 11559005]

11. Kar SS, Premarajan KC, Ramalingam A,, Iswayra S, Sujiv A, et al. Self-directed learning readiness among fifth semester MBBS students in a teaching institution of south India. Educ Health. 2014;27(3):289-92. PMID: 25758394

12. Shankar PR, Bajracharya O, Jha N, Gurung SB, Ansari SR, Thapa HS. Change in medical students' readiness for selfdirected learning after a partially problem-based learning first year curriculum at the KIST Medical College in Lalitpur, Nepal. Educ Health (Abington). 2011;24(2):1-10. [PMID: 22081659]

13. Deyo ZM, Huynh D, Rochester C, Sturpe DA, Kiser K. Readiness for self-directed learning and academic performance in an abilities laboratory course. Am J Pharm Educ. 2011;75(2):1-6. [PMID: 21519415]

14. Hawkins S, Hertweck M, Laird J, Goreczny AJ. Problem-based learning readiness: Evaluation of physician assistant readiness for group learning. Int $J$ Med Pharm. 2013;1(1):14-21

15. Hawkins S, Hertweck M, Goreczny A, Laird J. Student expectations of problem-based learning (PBL). Med Teach. 2013;35(6):525. [PMID: 23464897]

16. Hawkins S, Hertweck M, Goreczny A, Laird J. Effect of two semesters of small group problem-based learning (PBL) on expectations of physician assistant students regarding self, others, and facilitator using the PBL Readiness Questionnaire. IJAHSP. 2016;14(1), ISSN1540-580X.

17. Kilgour JM, Grundy L, Monrouxe LV. A rapid review of the factors affecting healthcare students' satisfaction with smallgroup, active learning methods. Teach Learn Med. 2016;28(1):15-25. [PMID: 26787081]

18. Chan CKY. Facilitators' perspectives of the factors that affect the effectiveness of problem-based learning process. Innov Educ Teach Int. 2016;53(1):25-34.

19. Wolf M, Wagner MJ, Poznanski S, Schiller J, Santen S. Not another boring lecture: Engaging learners with active learning techniques. J Emerg Med. 2015;48(1):85-93. [PMID: 25440868] 